\title{
Hydrogeophysical Investigation of Asaba Area, Delta State, Nigeria
}

Chinyem F. I.*

Department of Geology, Delta State University, Abraka; fichinyem@yahoo.com

\begin{abstract}
The vertical electrical sounding (VES) was employed in investigation for aquiferous units in Asaba area in Oshimili South Local Government Area of Delta state. Seven vertical electrical sounding were carried out in the study area using the schlumberger configuration with maximum current electrode spacing of $450 \mathrm{~m}-500 \mathrm{~m}$. The data was interpreted quantitatively and using the conventional curve matching and computer iteration method. The result revealed four to five geoelectric layers, with resistivity values ranging from $45.8 \Omega \mathrm{m}$ m to $1707 \Omega \mathrm{m}, 59 \Omega \mathrm{m}$ to $3434.9 \Omega \mathrm{m}, 83.2 \Omega \mathrm{m}$ to $5725 \Omega \mathrm{m}$ and $133.4 \Omega \mathrm{m}$ to $12693.4 \Omega \mathrm{m}$ for the first, second, third and forth/fifth layers respectively. The lithologies consisting of lateritic top soil, clay, fine medium and coarse grained sands with varying thickness. The aquiferous units were mostly confined and the results from this study were found to be consistent with some lithologic logs obtained from boreholes drilled in the study area.
\end{abstract}

Keywords: Hydrogeophysical, Investigation, Asaba, Aquiferious Units, Confined.

\section{Introduction}

The impact of increased industrialization and urbanization on groundwater, have led to an increased demand for potable water to cater for both industrial and domestic needs. Water is one of the essential necessities of nature, indispensable to all organic life, plant and animals development. It occurs in springs, rivers, streams and lakes in surface basins, falls as rain and occurs in the subsurface in porous, permeable rocks formation as ground water.

Groundwater provides one of the best sources of potable water for agricultural industrial and human development. This water is stored in and moves slowly through layers of soil, sand and rock called aquifers. An aquifer is a wet underground layer of water bearing permeable rocks or unconsolidated material (gravel, sand, silt or clay) from which underground water can be extracted. The availability of groundwater at any place generally depends on rainfall, snowmelt, structure of earth's material, and the porosity and permeability of the rock [6].

* Corresponding author:

Chinyem F. I. (fichinyem@yahoo.com)
The location of aquifers by subsurface investigation is a preliminary assignment in water development scheme of any community. Boreholes could be problematic, if thorough understanding of the surface geology is not known [4].

Generally, a number of geophysical methods are used in investigating the nature of water bearing layered. Notably among them is the seismic refraction, electromagnetic and electrical methods. The choice of a particular method is governed by the nature of the terrain. The superiority of the electrical resistivity over others in groundwater investigation was confirmed by the work of Zohdy [10]. The intimate relation between ground waters and its host rock has made geology a salient factor in ground water exploration, exploitation and development. Nevertheless the high rate of borehole failures across the country and Asaba in particular has necessitated the hydrogeophysical study of the area. Presently, provision of potable water via water supply scheme for the area is grossly inadequately. This called for the detailed hydrogeophysical investigation of the area and survey of ground water distribution in order to locate sites 
for drilling boreholes that would have a good yield. This research therefore is aimed at investigating the near surface formation in the area with respect to the depth of water in bearing formation.

\section{Location and Geology of Study Area}

The study area (Figure 1) is located within longitude $06^{0} 37^{1} \mathrm{E}$ and $06^{0} 45^{1} \mathrm{E}$ and latitude $06^{0} 05^{1} \mathrm{~N}$ and $06^{0} 17^{1} \mathrm{~N}$.

It is the capital of Delta state and is located within the northern flank of the Niger Delta Basin. The area is accessible by good road network, footpaths and the River Niger.

The area is well drained by two rivers, River Atakpo and River Anwai and the drainage pattern is basically dentritic. Because the soil is porous, the surface water is recharged by run off and is infiltrated. Subsurface water is also available from the underlying Formations: The Pleistocene to Recent Alluvium, the Eocene Ogwashi - Asaba Formation and the Oligocene - Miocene Ameki formation. The Alluvium is presently the most exploited aquifer and all others are untapped [2].

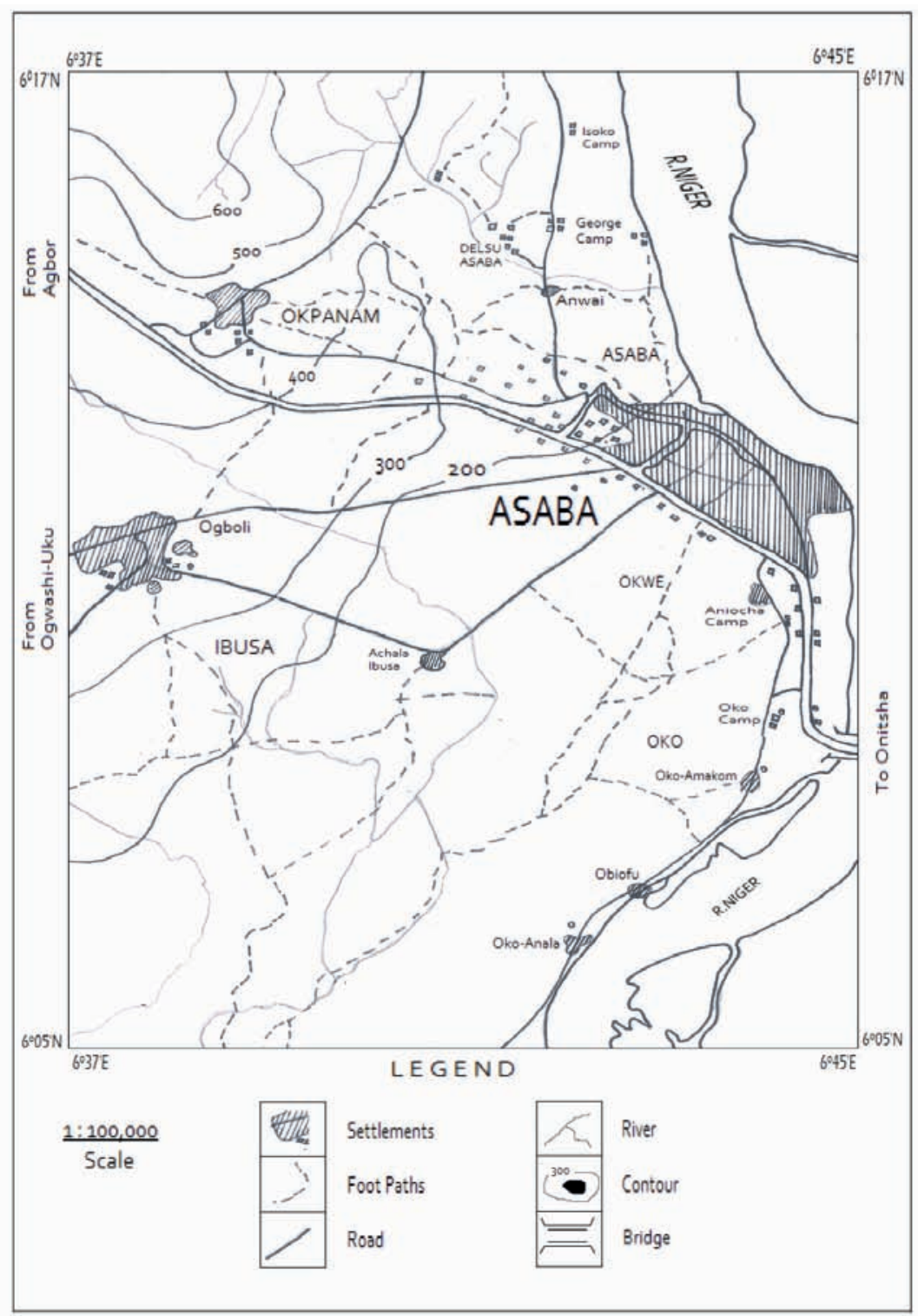

Figure 1. Location map of the study area. 


\section{Materials and Methods}

The Vertical Electrical Sounding (VES) by adopting the schlumberger method was carried out at preferred points in the study area (Figure 3). In this depth sounding mode, a series of measurements were made with increasing separation between the electrodes about the mid point. The electrode spacing $(\mathrm{AB} / 2)$ varied from 1 to between $300 \mathrm{~m}$ and $500 \mathrm{~m}$ depending upon field condition. A total of seven VES positions were occupied. The ABEM SAS 1000 portable terrameter having an inbuilt booster was used for the data acquisition. It could compute and display the apparent resistivity of the subsurface layer with the input data of the electrode configuration, the current and potential electrode separation. The observed field data was used to produce depth sounding curve (Figure 4). Quantitative interpretation of the data was done with both curve matching and computer assisted iterative methods using the resist software [9]. The computer modeling utilized the partial curve matching results (layer resistivity and thickness) as starting models. The geologic interpretation of the VES results was aided by the lithologic logs from the same boreholes in the area. The results obtained from the computer modeling are presented in table $i$.

\section{Theory}

The electrical resistivity method has been the most widely applied for delineating formation strata and groundwater investigations because of its portability in equipment, ease of operation and usefulness in efficient and economic drilling programmes [3]. The Schlumberger array was used in the subsurface investigation (Figure 2).
The resultant potential at electrode c, due to the two current electrodes is;

$$
\mathrm{V}_{\mathrm{c}}=\frac{\mathrm{eI}}{2 \pi}\left(\frac{1}{\mathrm{AC}}-\frac{1}{\mathrm{CB}}\right)
$$

Similarly, the resultant potential at D, due to the two current electrodes is

$$
\mathrm{V}_{\mathrm{d}}=\frac{\mathrm{eI}}{2 \pi}\left(\frac{1}{\mathrm{AD}}-\frac{1}{\mathrm{DB}}\right)
$$

Thus, the potential difference $\left(\mathrm{V}_{\mathrm{C}}-\mathrm{V}_{\mathrm{D}}\right)$ between the two inner electrodes measured by the voltmeter connected between $\mathrm{C}$ and $\mathrm{D}$ is;

$$
\Delta \mathrm{V}=\left(\mathrm{V}_{\mathrm{C}}-\mathrm{V}_{\mathrm{D}}\right)=\frac{\mathrm{eI}}{2 \pi}\left\{\left(\frac{1}{\mathrm{AC}}-\frac{1}{\mathrm{CB}}\right)-\left(\frac{1}{\mathrm{AD}}-\frac{1}{\mathrm{DB}}\right)\right\}
$$

Hence, from [8].

$$
\begin{aligned}
\mathrm{e} & =2 \pi \frac{\Delta \mathrm{V}}{\mathrm{I}}\left\{\frac{1}{\left(\frac{1}{\mathrm{AC}}-\frac{1}{\mathrm{CB}}\right)^{-}\left(\frac{1}{\mathrm{AD}}-\frac{1}{\mathrm{DB}}\right)}\right\} \\
& =2 \pi \mathrm{r}\left\{\frac{1}{\left(\frac{1}{\mathrm{AC}}-\frac{1}{\mathrm{CB}}\right)^{-}\left(\frac{1}{\mathrm{AD}}-\frac{1}{\mathrm{DB}}\right)}\right\} \\
& =\pi \frac{(\mathrm{AB} / 2)^{2}-(\mathrm{CD} / 2)^{2}}{\mathrm{CD} / 2} \frac{\mathrm{V}}{\mathrm{I}} \\
& =\frac{\mathrm{KV}}{\mathrm{I}}
\end{aligned}
$$

where $\mathrm{K}$ is the geometric factor and

$\mathrm{AB} / 2 \geq 5 \mathrm{CD}[3]$.

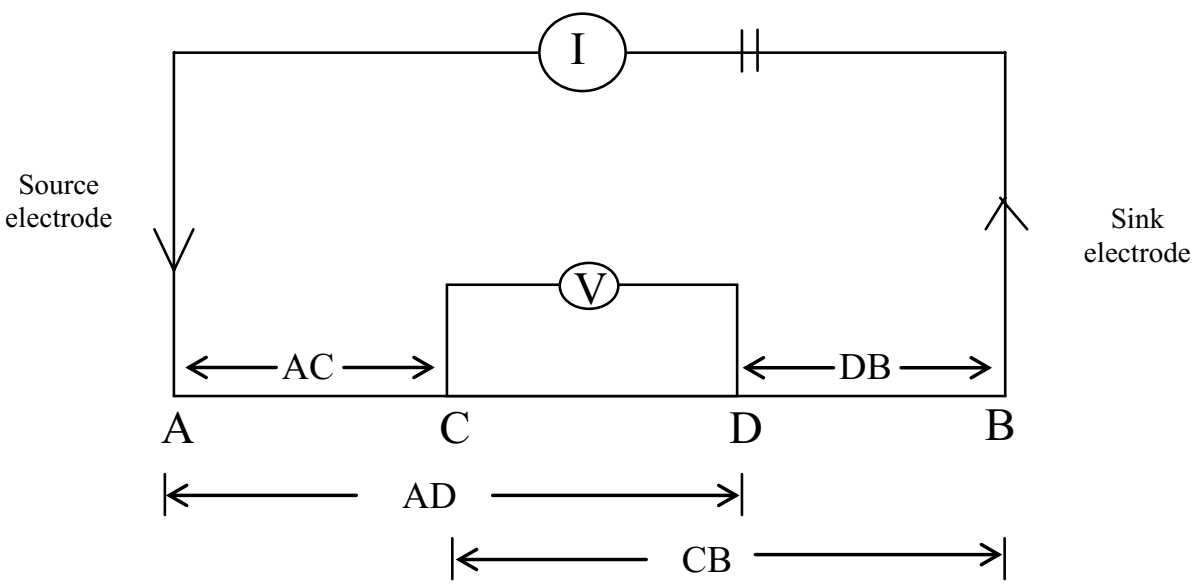

Figure 2. Four electrode Schlumberger configuration with ABEM SAS 1000 Terrameter [3]. 


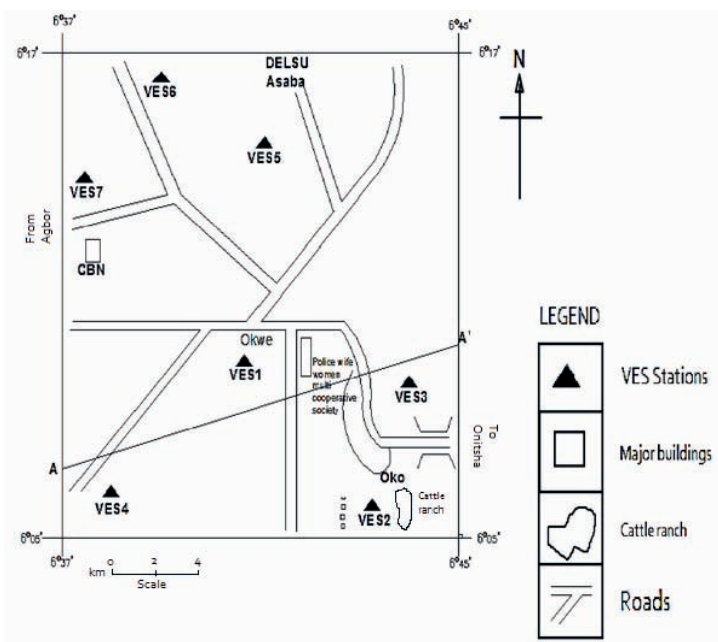

Figure 3. Data acquisition map of the study area.

\section{Results and Discussion}

The results of the investigation are presented as table, sounding curves and geo-electric section.

Table i shows the geo-electric layer parameters deduced from computer iteration and modeling of VES curves in the study area. The model curve type ranges from four to five layers, HK, AAK, KQ, HA, AK, KQ curve types. (Figure 4 and Table i). Figure 5 and 6 shows the geoelectric section of the study area.

The first layer has resistive values ranging from $45.8 \Omega \mathrm{m}$ (VES2) to $17 \Omega \mathrm{m}$ (VES1), which are inferred to be clay and lateritic soil respectively with thickness ranging from 0.7 $\mathrm{m}$ to $2.0 \mathrm{~m}$. A clayey sand and fine grained lateritic sand commonly constitute superficial deposits in the area. The

Table i. Geoelectric layers parameters deduced from computer iteration and modeling of the VES curves in the study area

\begin{tabular}{|c|c|c|c|c|c|c|}
\hline VES station & $\begin{array}{l}\text { Layer } \\
\text { No }\end{array}$ & $\begin{array}{c}\text { Resistivity } \\
\quad \Omega \mathrm{m}\end{array}$ & $\begin{array}{l}\text { Thickness } \\
\text { (m) }\end{array}$ & $\begin{array}{c}\text { Depth } \\
\text { (m) }\end{array}$ & Lithology & $\begin{array}{l}\text { Model curve } \\
\text { types }\end{array}$ \\
\hline VES & 1 & 1707.9 & 0.7 & 0.7 & \multirow{4}{*}{$\begin{array}{l}\text { Lateritic Topsoil } \\
\text { Medium } \\
\text { Coarse Sand } \\
\text { Coarse Sand }\end{array}$} & \multirow{4}{*}{$\begin{array}{l}\mathrm{HK} \\
\mathrm{p}_{1}>\mathrm{p}_{2}<\mathrm{p}_{3}>\mathrm{p}_{4}\end{array}$} \\
\hline \multirow[t]{3}{*}{ Okwe } & 2 & 833.7 & 3.3 & 4.0 & & \\
\hline & 3 & 5635.6 & 35.0 & 39.0 & & \\
\hline & 4 & 4429.5 & --- & --- & & \\
\hline \multirow{5}{*}{$\begin{array}{l}\text { VES2 } \\
\text { OKO } \\
\text { (Omerigboma) }\end{array}$} & 1 & 45.8 & 1.5 & 1.5 & \multirow{5}{*}{$\begin{array}{l}\text { Clay } \\
\text { Clay } \\
\text { Clay } \\
\text { Medium-coarse sand } \\
\text { Grained-coarse Sand }\end{array}$} & \multirow{5}{*}{$\begin{array}{l}\mathrm{AAK} \\
\mathrm{P}_{1}<\mathrm{P}_{2}<\mathrm{P}_{3}<\mathrm{P}_{4}>\mathrm{P}_{5}\end{array}$} \\
\hline & 2 & 59.0 & 7.4 & 8.9 & & \\
\hline & 3 & 83.2 & 7.7 & 16.6 & & \\
\hline & 4 & 712.8 & 28.2 & 44.8 & & \\
\hline & 5 & 691.3 & - & - & & \\
\hline \multirow{4}{*}{$\begin{array}{l}\text { VES3 } \\
\text { Bonsaac Area, } \\
\text { Asaba. }\end{array}$} & 1 & 1035.8 & 0.9 & 0.9 & \multirow{4}{*}{$\begin{array}{l}\text { Lateritic -topsoil } \\
\text { Coarse sand Medium } \\
\text { coarse -sand } \\
\text { Medium sand }\end{array}$} & \multirow{4}{*}{$\begin{array}{l}\mathrm{KQ} \\
\mathrm{p}_{1}<\mathrm{p}_{2}>\mathrm{p}_{3}>\mathrm{p}_{4}\end{array}$} \\
\hline & 2 & 3434.9 & 5.8 & 6.7 & & \\
\hline & 3 & 1934.7 & 37.4 & 37.4 & & \\
\hline & 4 & 467.0 & - & - & & \\
\hline \multirow{4}{*}{$\begin{array}{l}\text { VES4 } \\
\text { College Of } \\
\text { Education } \\
\text { Asaba }\end{array}$} & 1 & 699.8 & 0.9 & 0.9 & \multirow{4}{*}{$\begin{array}{l}\text { Lateritic top soil } \\
\text { fine-medium sand } \\
\text { coarse sand }\end{array}$} & \multirow{4}{*}{$\begin{array}{l}\mathrm{HA} \\
\mathrm{P}_{1}>\mathrm{P}_{2}<\mathrm{P}_{3}<\mathrm{P}_{4}\end{array}$} \\
\hline & 2 & 613.2 & 2.6 & 2.6 & & \\
\hline & 3 & 3842 & 45.8 & 45.8 & & \\
\hline & 4 & 4595 & - & - & & \\
\hline \multirow{4}{*}{$\begin{array}{l}\text { VES5 } \\
\text { Delsu, Asaba }\end{array}$} & 1 & 478.6 & 1.2 & 1.2 & \multirow{4}{*}{$\begin{array}{l}\text { lateritic-top soil } \\
\text { clay } \\
\text { coarse sand } \\
\text { coarse sand }\end{array}$} & \multirow{4}{*}{$\begin{array}{l}\mathrm{HA} \\
\mathrm{P}_{1}>\mathrm{P}_{2}<\mathrm{P}_{3}<\mathrm{P}_{4}\end{array}$} \\
\hline & 2 & 73.3 & 5.3 & 6.4 & & \\
\hline & 3 & 5725 & 15.0 & 21.4 & & \\
\hline & 4 & 12693.4 & - & - & & \\
\hline \multirow{4}{*}{$\begin{array}{l}\text { VES } \\
\text { Okpanam }\end{array}$} & 1 & 995.1 & 1.0 & 1.0 & \multirow{4}{*}{$\begin{array}{l}\text { lateritic-top soil } \\
\text { Medium coarse sand } \\
\text { Coarse sand } \\
\text { Coarse sand }\end{array}$} & \multirow{4}{*}{$\begin{array}{l}\mathrm{AK} \\
\mathrm{P}_{1}<\mathrm{P}_{2}<\mathrm{P}_{3}>\mathrm{P}_{4}\end{array}$} \\
\hline & 2 & 1752.2 & 3.8 & 4.8 & & \\
\hline & 3 & 3304.6 & 65.3 & 70.1 & & \\
\hline & 4 & 3247.3 & - & - & & \\
\hline VES7 & 1 & 377.1 & 2.0 & 2.0 & lateritic topsoil & KQ \\
\hline Opp. Central & 2 & 1283.3 & 8.0 & 9.9 & \multirow{3}{*}{$\begin{array}{l}\text { coarse sand } \\
\text { fine-medium sand } \\
\text { clayey sand }\end{array}$} & \multirow{3}{*}{$\mathrm{P}_{1}<\mathrm{P}_{2}>\mathrm{P}_{3}>\mathrm{P}_{4}$} \\
\hline \multirow[t]{2}{*}{ Bank Asaba } & 3 & 384.8 & 23.3 & 33.2 & & \\
\hline & 4 & 133.4 & - & - & & \\
\hline
\end{tabular}




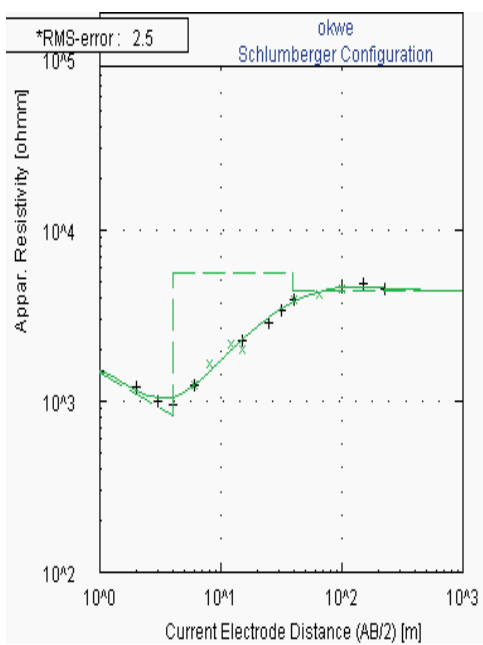

Figure 4a Computer iterated curves for VES 1.

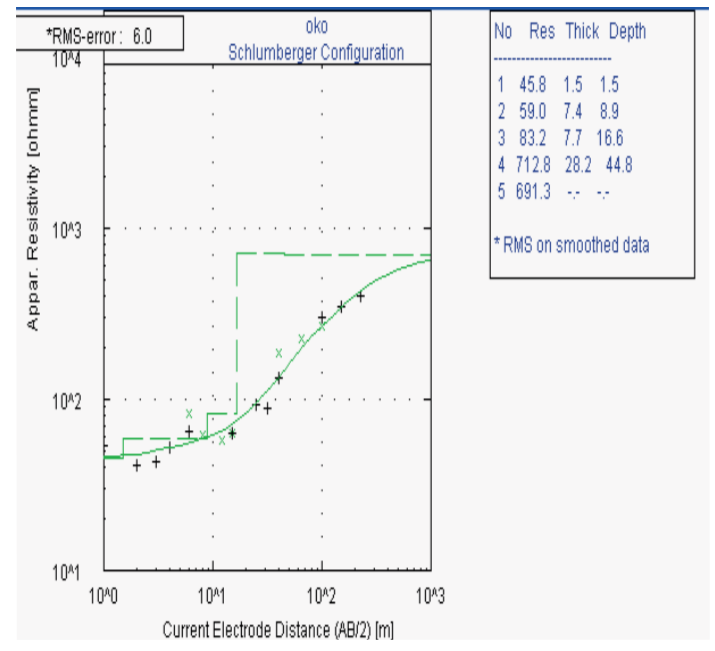

Figure 4b. Computer iterated curves for VES 2.

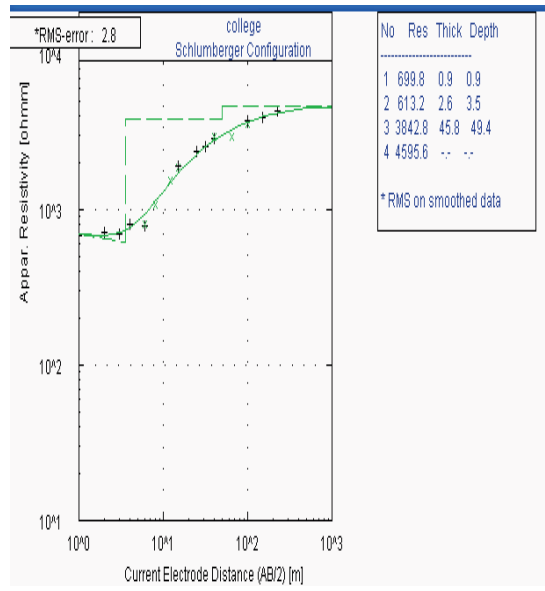

Figure 4c. Computer iterated curves for VES 4.

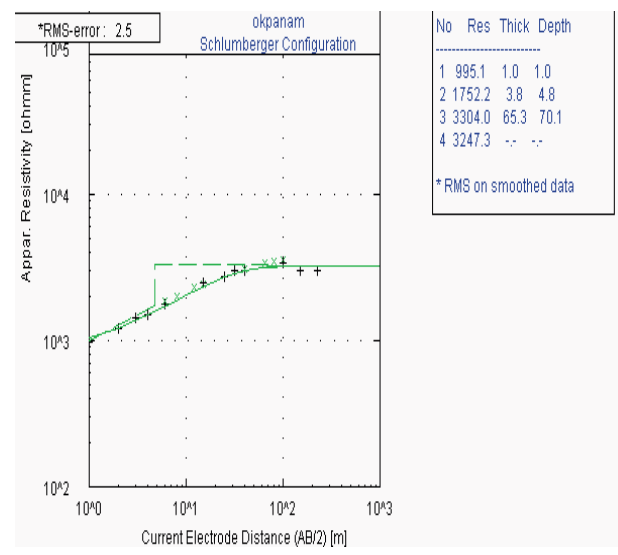

Figure 4d. Computer iterated curves for VES 6

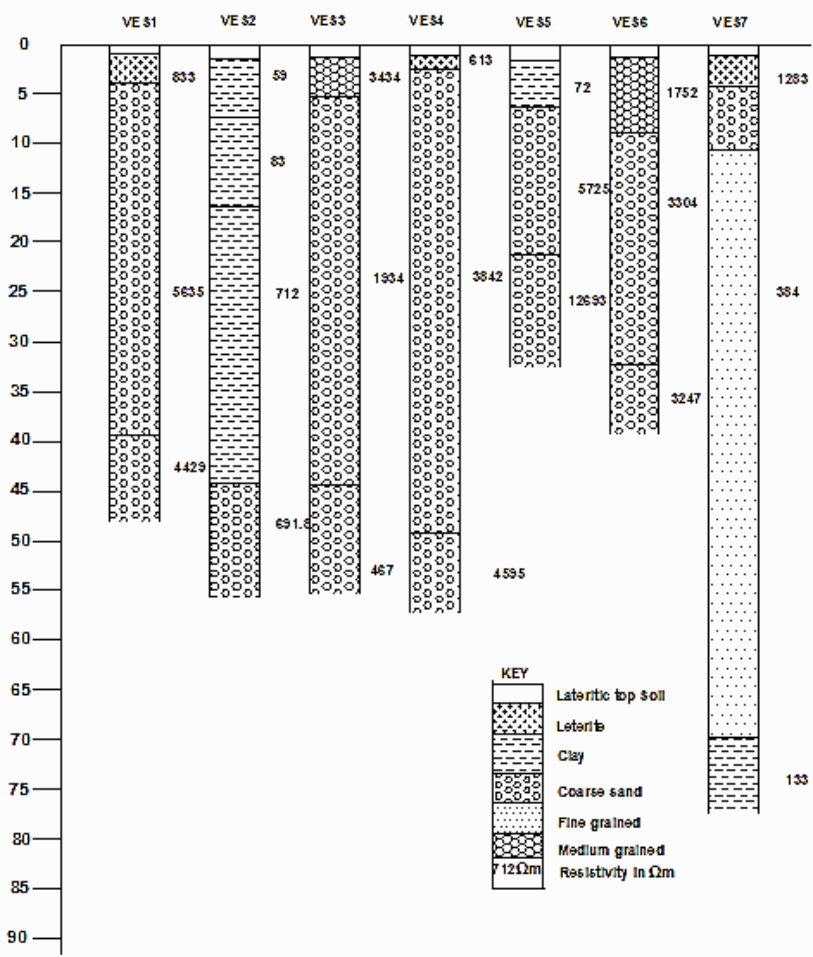

Figure 5. Geoelectric section of the study area.

second area has resistivity values ranging from $59 \Omega \mathrm{m}$ (VES2) to $3434.9 \Omega \mathrm{m}$ (VES3), with thickness ranging from $2.6 \mathrm{~m}$ to $9.9 \mathrm{~m}$. The deduced lithologies include sand, clay, coarse to medium grained sand. The third resistivity values range from $83.2 \Omega \mathrm{m}$ (VES2) to $5725 \Omega \mathrm{m}$ (VES5) within a depth range of $16.6 \mathrm{~m}$ to $70.1 \mathrm{~m}$ and thickness of between $15.0 \mathrm{~m}$ to $65.3 \mathrm{~m}$. The inferred lithology types include clay and coarse grained sand. The fourth layer has resistivity values ranging from 133.4 $\Omega \mathrm{m}$ (VES7) to $12693.4 \Omega \mathrm{m}$ 


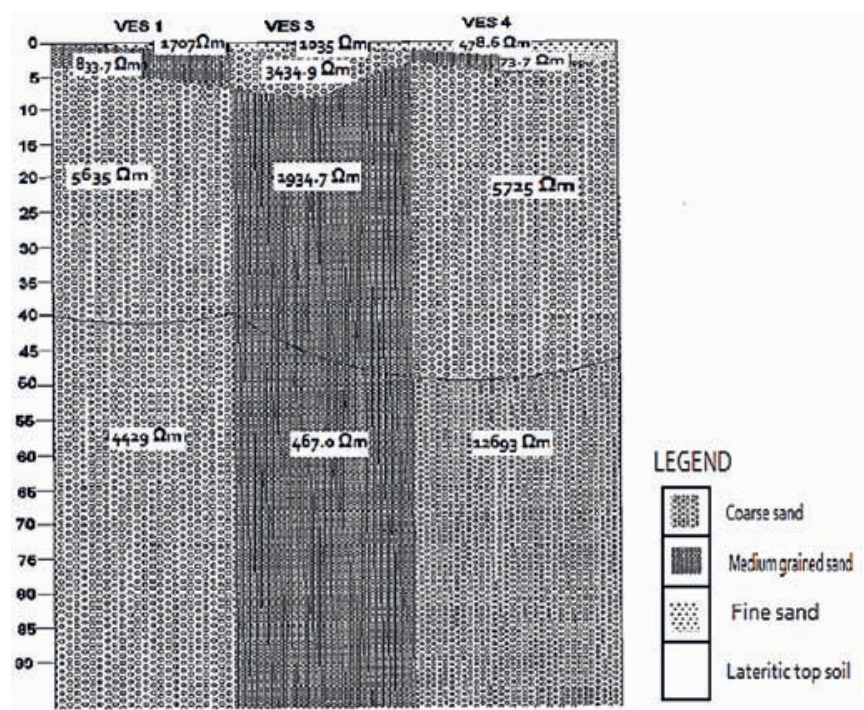

Figure 6. Geoelectric section from profile AA' showing near surface lithologic distribution.

(VES5). The inferred lithology includes sand, clay and medium to coarse grained sand, spanning and infinite depth range and infinite thickness. The exact thickness of this layer cannot be determined as the electrode terminated within this layer.

The presence of clay in the first, second and third layers of VES and the second layer of VES are attributed to the presence of in situ weathered clay. Thus this layer is commonly water saturated and is often characterized by low resistivity, high porosity, low specific yield, and low permeability [7]. A semi-confirmed aquifer condition may be created if the clay content is very thick. On the other hand the main aquiferious zone may be found at the base of the weathered profile where minerals decomposition resulting from in situ chemical weathering has produce gravel-like materials of moderate to high permeability $[7,1]$. Thus for viable aquifers, suggested sites for high yield boreholes are at VES 2, VES 4 and VES 6 respectively. The interpreted geoelectric data correlates with the lithologic log of boreholes drilled to a depth of $120 \mathrm{~m}$ at Okpanam close to VES 6 [5].

\section{Conclusion}

Seven schlumberger vertical electrical soundings were carried out in Asaba area of Delta state. The result of the geo-electricinvestigation revealed geo-electriclayers namely the lateritic-topsoil, clay/clayey sand and sand (medium to coarse grained sand) that are in actual agreement with the actual lithology encountered from the borehole logs. Based on the geo-electric investigation carried out, aquifer type is mainly confined aquifer (artesian), and it is highly recommended boreholes in the area should be drilled to a depth of about $45 \mathrm{~m}-80 \mathrm{~m}$ in order to have good and reliable water yields, more especially at sites of VES 2, VES 4 and VES 6 respectively. It is equally recommended that a good rig should be employed in drilling especially in the Oko area where clayey formation is encountered. Also drilling should be supervised by an experience geologist, so as to discriminate between types of sand and ensure that drilling adequately penetrate the water table. More importantly, results of the geo-electric sounding correlates well with that of drilling. This paper has provided an insight in the use of surface electrical resistivity survey in delineating the sub-surface formation in Asaba area.

\section{References}

1. Aeworth, R I (1987). The development of crystalline basement aquifers in a tropical environment, Quarterly Journal of Engineering Geology, vol 20, 265-272.

2. Akpoborie, A I, and Etobro A I (2006). Aspect of the geology and water resource of Asaba, Nigeria- (Abstract), $18^{\text {th }}$ National Conference of Nigeria, Association of Hydrogeologists, 39 .

3. Todd D K (1980). Groundwater hydrology, $2^{\text {nd }}$ Edn., John Wiley Inc, New York, 409-428.

4. Chinyem, F. I. (2011). Geo-electric evaluation of ground water potential. A case study of Sabongida-ora and environs, Southern Nigeria, Journal of applied Science and Environment, vol 15(4), 629-633.

5. DSMWR, (2008). Delta State Ministry of Water Resource borehole lithologic log, Asaba.

6. Grifiths D H, and Kings F F (1965). Applied geo-Physics for Engineers and Geologist, $2^{\text {nd }}$ Ed., Pergamon Press, England.

7. Jones M J (1985). The weathered zone aquifer of the basement complex of Africa, Quarterly Journal of Engineering Geology, vol 18(1), 35-46.

8. Okolie E C, Osemeikhian J E et al. (2005). Estimate of groundwater in parts of Niger Delta of Nigeria using geoelectric method, Journal of Applied Science and Environmental Management, vol 9(1), 31-37.

9. Vander V B P A (1988). Resist version 1.0, MSc research project ITC, Deft, Netherlands.

10. Zohdy A R (1973). The use of schlumberger and electric soundings in ground water investigation near El Paso, Texas. Geophysics, vol 34, 7-13. 